\title{
ELMONDANI AZ ELMONDHATATLANT
}

Az elmondani az elmondhatatlant kifejezés problémás természete nyelvileg elsőként abban nyilvánul meg, hogy egyirányúnak hat, az elmondó fél korlátaira fókuszál, annak ellenére, hogy fogalmilag valójában a hallgatóság performatív oldaláról is szól. A nemi erőszak eseményének elmondhatósága pedig az átadásban is rejlik, két fél közötti kommunikációs lehetöségben (vagy lehetetlenségben), amelyben a befogadó szinte nagyobb szerepet játszik, mint az elmondó. Az a befogadó, aki könnyen gátja lehet annak, hogy a nemi erőszak élménye egyáltalán elmondható legyen. Pető Andrea a második világháborús nemi erőszakról szóló könyvének címe ezenkívül többrétü jelentést is hordoz, mert feminista elméleti alapon egy olyan országban hívja fel a figyelmet a női áldozatok megszólaltatásának jelentőségére, ahol a kiadás évében rendeletileg, mindennemü hivatalos konzultáció vagy tudományos intézet bevonása nélkül szüntették meg az ennek gondolati alapját szolgáló társadalmi nemek tanulmány szakot.

Mindemellett Pető sikeresen szólítja meg a jelenleg is problematikus második világháborús emlékezetpolitikánkat, mellyel az ország önmagáról alkotott történelmi képének módosítását kezdeményezi. Ideológiai harcok helyett hangsúlyosabban a kegyetlenségek által okozott emberi szenvedésekröl olvashatunk, mely során az is nyilvánvalóvá válik, hogy történelmi tudásunkat eddig leginkább az diktálta, hogy az adott kor nemzeti identitása éppen a felszabadulás vagy az ostromlott narratíváját készül magára ölteni. Az így kialakult zavaros váltakozó értelmezési keretek vezettek az elkövetö-tudatos mártíromság irányelv felé, mely diskurzus mindig is figyelmen kívül hagyta a valós áldozatokat. Pető Andrea munkája azonban sikeresen tereli vissza figyelmünket a második világháborús nemi erőszak elszenvedőire, és teremt talajt a nők háborúban betöltött szerepének párbeszédéhez. Ezzel a kötet nem csupán reflektál bonyolult emlékezetpolitikánkra, hanem egyben fontos részévé is válik. Ehhez interdiszciplináris gondolatisággal vonja be a témát felölelő magyar filmtörténet fontos müveit és recenzióit, a korabeli fényképek értelmezési lehetőségeit, a szájhagyomány útján terjedő elbeszéléseket, a képzőmüvészeti alkotások politikai szerepeit és sok más fontos müvészeti vagy közszférában megjelenő megnyilvánulást. A második világháborús nemi erőszak holisztikus történetét Pető közérthető nyelvezettel és átlátható struktúrával mutatja be, így a könyv a szakmai diskurzuson túl szélesebb közönséget is képes elérni, s ezzel a történelmi emlékezetről szóló közbeszéd részévé válni.

Sára Sándor $A$ vád címü filmkritikájának analógiájaként a könyv első része a szovjetek által elkövetett nemi erőszakról való beszéd hiányos természetét és a női vallomások tabusítását taglalja, amelynek végét - s ezzel egyben a feminis- 
ta értelmezés lehetőségének kezdetét - a rendszerváltás hozza el. Azzal, hogy Pető a történelmi gondolkodás középpontjába feminista elméleti megközelítéseket helyezett, többek között olyan lényeges nézőpontváltást ér el, amely lehetővé teszi a korábban elnyomott női hangok felszínre jutását, legyen az egy interjú, önéletrajzi írás, müvészi megnyilvánulás vagy akár egy akadémiai diskurzus formájában. Ezt követően a különböző nemi erőszak típusok elméleti hátterét mutatja be, melyeknek értelmezését a hatalmi viszonyok kérdésére alapozza. Ennek komplexitását azzal a figyelmeztetéssel tárja elénk, hogy a tömeges nemi erőszak megértéséhez a szovjetek kiragadása önmagában nem elegendő, mivel ebben az időszakban minden katona - még a magyar katonák is - részesei voltak ennek a militáns kultúrának. Sőt, két okból azt is kihangsúlyozza, hogy a nemi erőszak elkövetőiként nem kizárólag férfiakra kell gondolnunk. Ez az általánosítás egyrészröl leegyszerüsítené az egyes csoportok vagy társadalmak összetett hatalmi struktúráinak megértését, másrészről pedig kimutatható, hogy sok esetben az áldozatok férfiak voltak. Ezen kérdéskör összetettségéből kiindulva a szerző megkérdőjelezi a második világháborús nemi erőszak statisztikai mutatóit, a mérés fogalmi problémáira hivatkozva. A módszertani és historiográfiai áttekintés után a kötet a háborús nemi erőszak mai emlékeit különböző kulturális termékek bemutatásával vizsgálja, melynek irányultságát az áldozatok viszonylagos némasága is adja. A történész több mint tízéves kutatása sikeresen ötvözi a vallomásokat a játékfilmekkel, dokumentumfilmekkel, fényképekkel, sőt még online kommentek egyvelegével is, hogy megérthessük a tabusítás különböző folyamatait és az emlékezés politizálódását. Ennek a kiterjedt folyamatnak az egyik legbeszédesebb példájaként Jerzy Bohdan Szumczyk Komm, Frau címü gdański emlékmüvét és az azt követő hangos felháborodást említi, amely kiválóan mutatja a jelenkori társadalom reakcióját.

A könyv utolsó részében Pető az általában figyelmen kívül hagyott szovjet oldallal egészíti ki kutatását. A több online platformon is végzett vizsgálat széles spektrumában az orosz nyelvü áldozatok, tanúk, és elkövetők is megszólalnak, amely eredmény további kutatás és egy megújult diskurzus fontos alapjául szolgálhat. Mindemellett a szerző gondosan áttekinti Oroszország és Ukrajna emlékezetpolitikai harcát, mely a ,ki a fasiszta” kérdéskörben összpontosul. Az ennek megfejtésére igyekvő történészek a náci és szovjet struktúrák összehasonlítására koncentrálnak, s e megközelítés félrevezető jellege többek között abban is megnyilvánul, hogy az ukrán történelmi diskurzus a nemi erőszakot elkövető katonákat szovjet helyett már oroszként említi. Az ilyen jellegü eszközösítés és etnicizálás szintén elveszi a figyelmet a lényegről: a háborús nemi erőszakkal való szembesülésröl. A szerző más különböző reakciókat is felsorol, fenntartva azt a fó álláspontját, hogy minden ehhez hasonló meglátás nehezíti a háborús nemi erőszak strukturális megértését, melynek tükrében torzulnak a történelmi narratívák, s végül a történelmi emlékezet. 
Összességében, Pető Andrea munkája sikeresen ragadja meg a második világháború egyik elnémított sötét oldalát együtt a mai problémás emlékezetpolitikánkkal. Átfogó kutatásának egy olyan interdiszciplináris történelemkönyv az eredménye, amely arra készteti olvasóját, hogy ahelyett, hogy szimplán visszahelyezné a könyvet a polcra, megnézze a háborús nemi erőszakról készült magyar filmeket, nyitottabbá váljon, és kritikai gondolkodást alakítson ki a müvészet befogadásánál, olvasson mai emlékezetpolitikát vitató cikkeket, s megpróbáljon egy paradigmaváltás részévé válni. Pető Andrea könyve az elnémított áldozatok erejét mutatja be, és a nemi erőszak nyílt megvitatását alapozza meg Magyarországon, hogy szembesülhessünk történelmünkkel egy jobb jövő reményében.

(Petö Andrea: Elmondani az elmondhatatlant. A nemi eröszak Magyarországon a II. világháború alatt. Budapest: Jaffa Kiadó, 2018, 278 o.)

Szabó Alexandra M.

PhD-hallgató, University of Oxford 